GEOLOGICAL SURVEY CIRCULAR 280

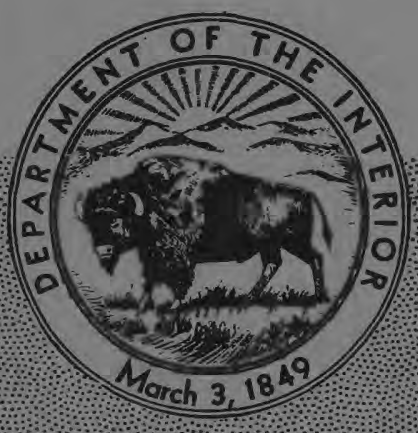

\title{
POTENTIAL INDUSTRIAL
}

SITES IN THE LYNN

CANAL AREA, ALASKA 
UNITED STATES DEPARTMENT OF THE INTERIOR

Douglas McKay, Secretary

GEOLOGICAL SURVEY

W. E. Wrather, Director

GEOLOGICAL SURVEY CIRCULAR 280

\section{POTENTIAL INDUSTRIAL SITES IN THE \\ LYNN CANAL AREA, ALASKA}

By Arthur Johnson and W. S. Twenhofel 


\title{
POTENTIAL INDUSTRIAL SITES IN THE LYNN CANAL AREA, ALASKA
}

\author{
By Arthur Johnson and W. S. Twenhofel
}

\author{
, CONTENTS
}

Page

Page

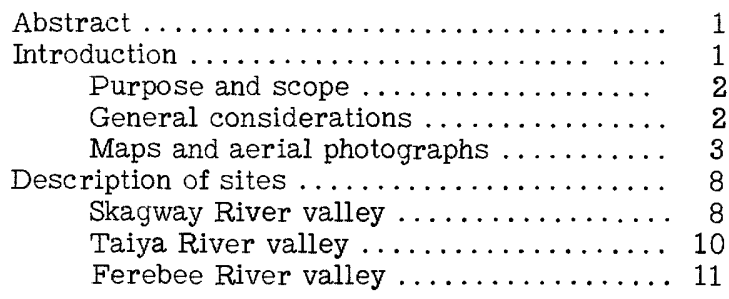

Description of sites -Continued

Lutak Inlet . ................. 11

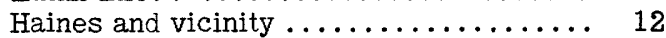

Klukwan and vicinity ................. 14

Haines to Klukwan ................ 14

Berners Bay ................... 15

Juneau and vicinity $\ldots \ldots \ldots \ldots \ldots \ldots \ldots, 16$

Recommendations ....................... 17

Literature cited ................... 17

ILLUSTRATIONS

Page

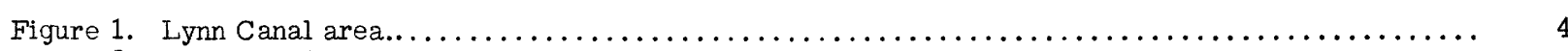

2. Mean monthly values, precipitation, and temperature at Skagway, Haines,

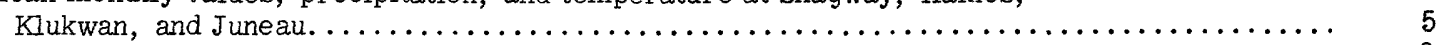

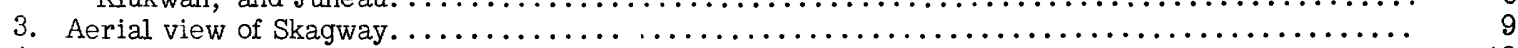

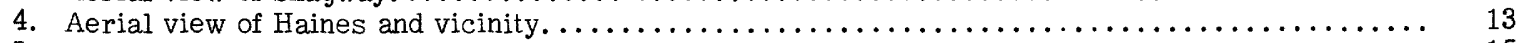

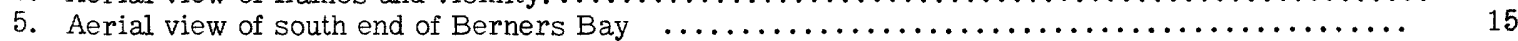

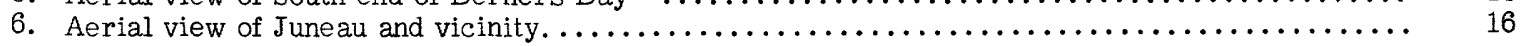

TABLE

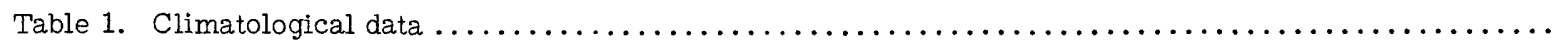

\section{ABSTRACT}

Full development of a proposal to divert the headwaters of the Yukon River drainage from Canada into the Taiya River valley of Alaska would make available more than a half million kilowatts of electrical energy. Utilization of this block of power, for which there is at present no local market, will require an industrial and community development of appreciable magnitude. Suitable sites for industrial and community development near the proposed power source are limited because of the extremely rugged and mountainous terrain of the Lynn Canal area.

This report considers potential industrial areas at Skagway, Taiya River, Ferebee River, Lutak Inlet, Haines and vicinity, Klukwan and vicinity, Haines to Klukwan along the Haines cutoff, Berners Bay, and Juneau and vicinity. The factors considered in their evaluation are topography, geology, climate, water supply, transportation facilities, and transmissionline routes from the source of power.

\section{INTRODUCTION}

It has long been known that a large block of hydroelectric power could be developed by diverting water from the headwaters of the Yukon River in Canada to some point in the Taiya River valley near Skagway, Alaska. Such a project would involve damming the Yukon River at Miles Canyon near Whitehorse, Yukon Territory, to develop storage in a series of interconnecting lakes and diverting from one of these lakes, Lake Lindeman, by tunnel through the Coast Range to a power site, or sites, in the Taiya River valley. The potential power would be a half million kilowatts or more, the exact amount being dependent on the amount of water that can be diverted. This plan is generally referred to as the Yukon-Taiya Project.

This project has an international aspect, involving the United States and Canada as well as Yukon Territory, the Province of British Columbia, and the Territory of Alaska. Obviously there must be 
proper agreement between the governmental units before any actual development can be undertaken.

The Aluminum Company of America (Alcoa) announced plans in August 1952 (Eng. News Record, 1952, p. 21) for developing the Yukon-Taiya Project at an estimated cost of $\$ 400$ million. According to this announcement the completed project would produce 200,000 tons of aluminum metal annually, would develop more than 1 million kilowatts of power, and would require an area of about 20,000 acres or more than 30 square miles. The construction and subsequent operation of the project would result in a town having an estimated population of 20,000 or more.

\section{Purpose and scope}

The purpose of this report is to present information relating to the various locations in Alaska where industrial communities might be established to use the power from the Yukon-Taiya Project. These locations are discussed considering the topography, geology, climatic conditions, water supply, transportation, and transmission-line requirements. The following locations are described: Skagway, Taiya River, Ferebee River, Lutak Inlet and Chilkoot Lake, Haines and vicinity, Klukwan and vicinity, Haines to Klukwan, Berners Bay, and Juneau. The general geographic and topographic conditions of the areas are shown on sheets 8 and 9 of the International Boundary Commission maps as well as on the Juneau, Skagway, and Atlin quadrangle maps, published by the U. S. Geological Survey (scale, 1:250, 000). More details of some of the areas are shown on quadrangle maps (scale, 1:63, 360) also published by the U. S. Geological Survey. Reference to these maps are made appropriately in the text that follows. Aerial views of Skagway, Haines, Berners Bay, and Juneau are shown in figures 3, 4, 5, and 6 . No attempt has been made to delineate specific areas or determine available acreages at the locations as map information now available makes this impracticable. Furthermore, what might be a suitable site for one type of industry would be unsuitable for another. Some industries might require a comparatively flat area whereas hillside topography would be advantageous for others.

\section{General considerations}

The entire Alaskan area under consideration is mountainous having altitudes that range from sea level to more than 5,000 feet. Deep water fiords, ice-free the entire year, extend far into the mountains. The only flat and subdued topography suitable for community and industrial use is in the larger river and stream valleys and along certain isolated portions of the coast. The mountain slopes are invariably too steep for the usual types of habitation and industrial installations.

All areas that can be described as flat, or nearly so, consist of sand and gravel or glacial till, most of which is easily excavated but in many cases is not a good foundation material for large industrial plants. Areas that could provide firm bedrock foundations are rare and have a sloping surface, generally quite steep.
Power generated in large blocks generally, can be transmitted distances up to 300 miles or more (Barrows, 1943, p. 572) to bring it to communities and load centers. At present neither large communities nor load centers exist within practicable transmission range. Therefore, an industrial development requiring the amount of potential power available must be plannec: and considered as part of the development of the project. Owing to the rugged topography and adverse climatic conditions the cost of transmissionline construction would be extremely high. Maintenance, particularly during winter months would also present a difficult problem. The foregoing conditions dictate the desirability of considering locations as close to the source of power as possible. Consequently, attention is first directed to the possible locations nearest the source of power and then working away, from there. Juneau, 90 miles from the source of power, is the most distant.

An adequate water supply, as to quantity and quality, is one of the most important considerations in evaluating the location of a possible industrial site. The demand for domestic water supply can be estimated reasonably well by reference to the demands of various cities. According to a report of the Water Division of Tacoma, Wash., the domestic consumption was $221 \mathrm{gpd}$ per capita for the year 1948. Anchorage, Alaska, uses between 300 and 400 gpd per capita during the winter months. A large part of this demand is due to the practice of leaving faucets slightly open during cold weather to prevent pipes from freezing. A properly designed and constructed system could unquestionably lower this amount appreciably. For estimating purposes in this report a domestic consumption of $300 \mathrm{gpd}$ per capita has been used. Assuming that a town with a population of 25,000 will result along with the industrial development, the water requirement would amount to $7.5 \mathrm{mgd}$ or 23 acre-feet per day which is equivalent to a flow of $11.6 \mathrm{cfs}$.

The requirements for industrial water supply vary widely with different industries. Until the type of industry and types of processes planned for the Yukon-Taiya Project are known, reliable estimates cannot be made. According to present indications the principal installations in the area under consideration will be made by the aluminum industry. Studies of the requirements for industrial water supply are now in progress by the Geological Survey. These studies show (Davenport, letter dated Dec. 24, 1952) that the main demand for water in the manufacture of aluminum is in the reduction of alumina to the aluminum metal. This process requires from 10 to 50 gallons per pound of finished aluminum metal. This wide variation is due to several considerations. Where water supplies are limited or where stream pollution is a factor, a high degree of recirculation can be employed in which case the demand can be as low as 10 gallons per pound. A "once through" system may be used when the demand is as much as 50 gallons per pound if water supplies are plentiful and stream pollution is not a factor. For a plant with a 400 million pound annual production of aluminum metal the corresponding water demands would range from 17 to $85 \mathrm{cfs}$.

The production of alumina from the bauxite ore requires about 1 gallon per pound of alumina. Two pounds of alumina are required to produce 1 pound of 
aluminum metal. Eight hundred million pounds of alumina would therefore be required to produce 400 million pounds of aluminum metal. Using the relationship of 1 gallon of water per pound of alumina results in a demand of $3.6 \mathrm{cfs}$. For the purpose of this report this figure can be disregarded as it is comparatively small in relation to the other needs and it seems unlikely that the bauxite ore would be shipped to Alaska for reduction to alumina.

As previously stated the main demand for water is in the reduction of the alumina to aluminum metal and the process may require as much as $85 \mathrm{cfs}$ for the development under consideration. For a report of this kind it seems advisable to consider the maximum demand that may occur or $85 \mathrm{cfs}$. This value along with the estimated $12 \mathrm{cfs}$ for domestic water supply totals 97 or about $100 \mathrm{cfs}$. This is equivalent to 72,000 acre-feet per year. This value is for the proposed development by the aluminum industry and the supporting community. It is probable that other industries may also develop which, along with the supporting community, would also require a large volume of water. For long range development studies water requirements of more than $100 \mathrm{cfs}$ should be considered. As final planning stages are approached and if water supplies are limited certain conservation measures may be employed to bring the requirements within the supplies readily available.

The contemplated industrial development will most likely fall in the class of electrochemical or electrometallurgical industries. Large volumes and tonnages of material will have to be handled, and the main transportation of raw materials to the sites and finished products to points of distribution will be by water. Harbor conditions are therefore an important consideration. These are shown on many U. S. Coast and Geodetic Survey charts.

The Lynn Canal (fig. 1) area has pronounced tidal variations. Any harbor construction must be designed to accommodate vessels throughout the entire tidal range. The elevations of the tide planes at Skagway (U. S. Coast and Geodetic Survey, 1941, p. 164) based on observations during the period September 1908 to August 1911 and referred to mean lower low water are as follows:

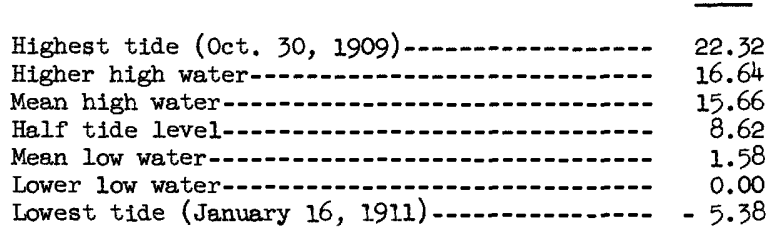

The foregoing table indicates that the extreme tidal variation may be close to 30 feet.

Fuel supplies, except wood, are not available at any of the locations considered and must ther efore be imported. Home heating in southeastern Alaska utilizes petroleum products extensively. Very little use is made of coal for this purpose.

Climatic conditions, although important, will not likely be the deciding factor in selection of suitable industrial sites. Climate is discussed, however, for the various suggested locations. Data on precipitation, snowfall, prevailing wind direction, and temperature at Skagway, Haines, Klukwan, and Juneau are shown in table 1. Mean monthly values for precipitation and temperature for these four stations are also shown graphically in figure 2.

Earthquakes have occured in the past throughout southeastern Alaska and can be expected to occur in the future at all of the locations discussed in this report. Yakutat Bay, about 150 to 175 miles northwest of Lynn Canal, experienced earthquakes in September 1899 that rank with the most intense earthquakes ever recorded in the World (Tarr and Martin, 1912, p. 128). In planning any largescale development in the Lynn Canal area the destructive effects of earthquakes should be considered.

As a development of this kind can be planned in advance, it seems logical to assume that the resulting communities can take advantage of the most up-to-date techniques and trends of city planning and avoid some of the undesirable features of many industrial centers in the United States. Proper zoning should remove residential areas from the industrial or factory sites. Among the factors to be considered in zoning, mention should be made of air pollution, maximum utilization of available sunlight, and disposition of industrial wastes.

\section{Maps and aerial photographs}

The areas under consideration are shown on the following maps:

\section{U. S. Geological Survey:}

Base maps:

Alaska map B, 1952. Scale, 1:1, 584, 000. Also shows adjacent areas of British Columbia and Yukon Territory.

Alaska map E, 1953. Scale, 1:2,500, 000. Also shows adjacent areas of British Columbia and Yukon Territory.

Alaskan Reconnaissance Series (scale, 1:250, 000): Atlin quadrangle, 1951. Contour interval, 250 feet.

Juneau quadrangle, 1950. Contour interval, 200 feet.

Skagway, 1953. Contour interval, 200, 250 , and 500 feet.

Quadrangle maps (scale, 1: 63, 360):

Juneau B-2, B-3, D-4, and C-3 (in preparation). Contour interval, 100 feet.

Skagway, A-1, B-1, C-1, and C-2, 1952. Contour interval, 100 feet.

Quadrangle maps (scale, 1:24, 000):

Juneau and vicinity, 1950. Contour interval, 40 feet.

U. S. Forest Service:

Tongass National Forest, 1951. Scale, 1:750, 000.

U. S. Coast and Geodetic Survey:

Charts: 8235 Gastineau Channel and Taku Inlet. Scale, 1:40, 000.

8302 Lynn Canal-Icy Strait to Point Sherman. Scale, 1:80, 000 .

8303 Lynn Canal-Point Sherman to Skagway. Scale, 1:80, 000 .

8202 Midway Islands to Cape Spencer, including Lynn Canal. Scale, 1:209, 978.

World aeronautical charts:

116 Mount Hunt. Scale, 1:1, 000, 000.

138 Mount Fairweather. Scale, 1:1,000,000. 


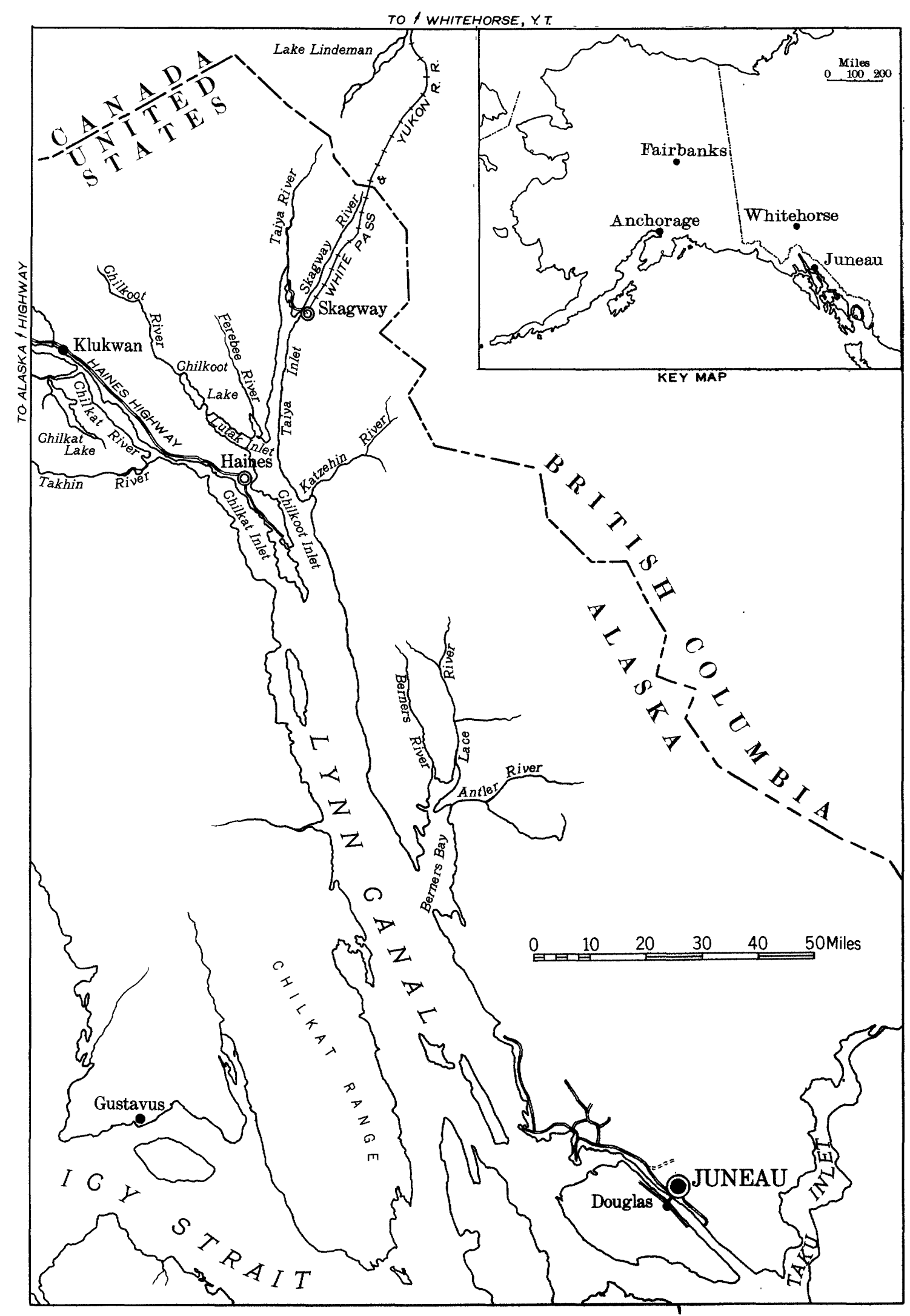

Figure 1. - Lynn Canal area. 


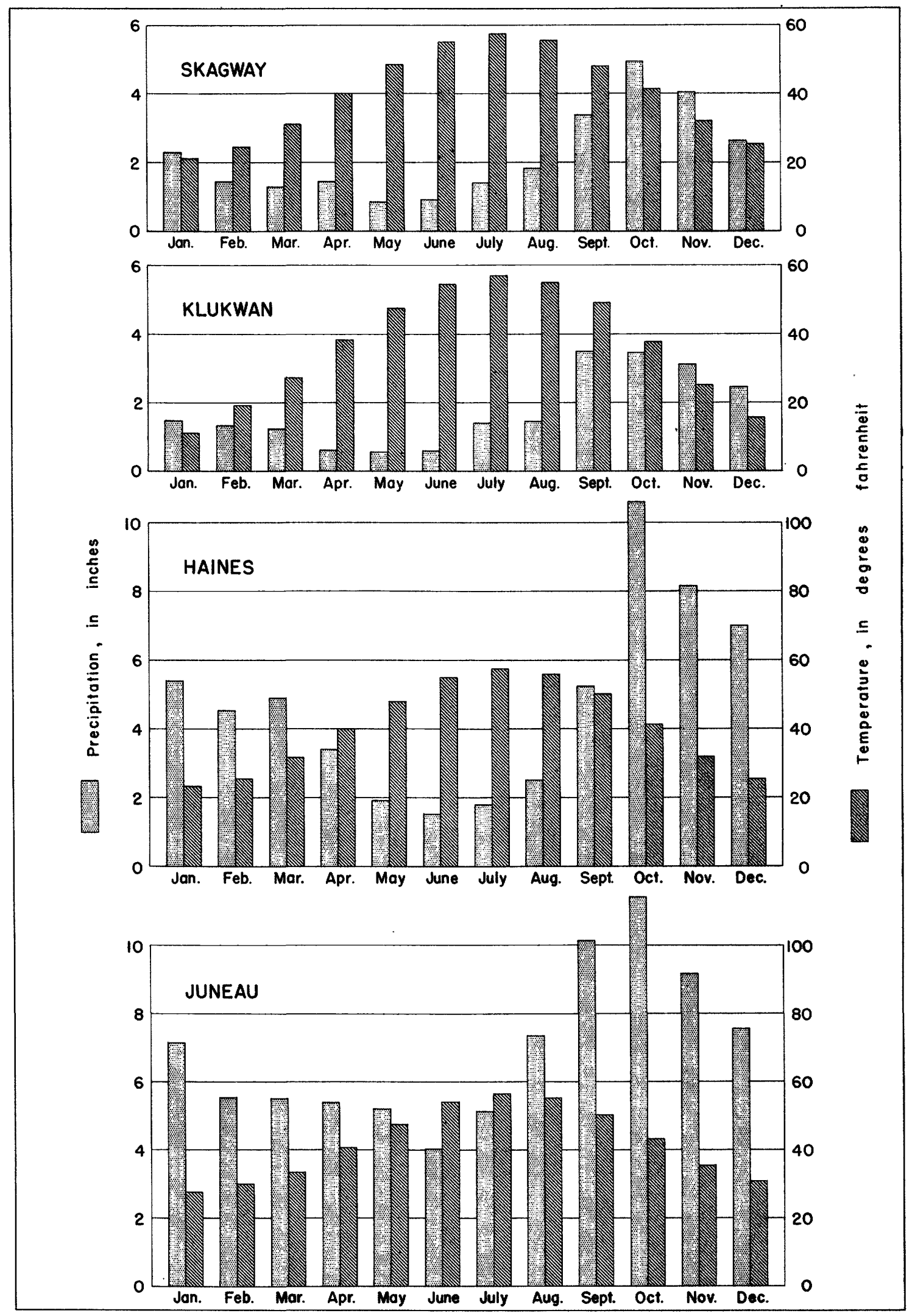

Figure 2. - Mean monthly values, precipitation, and temperature at Skagway, Haines, Klukwan, and Juneau. 


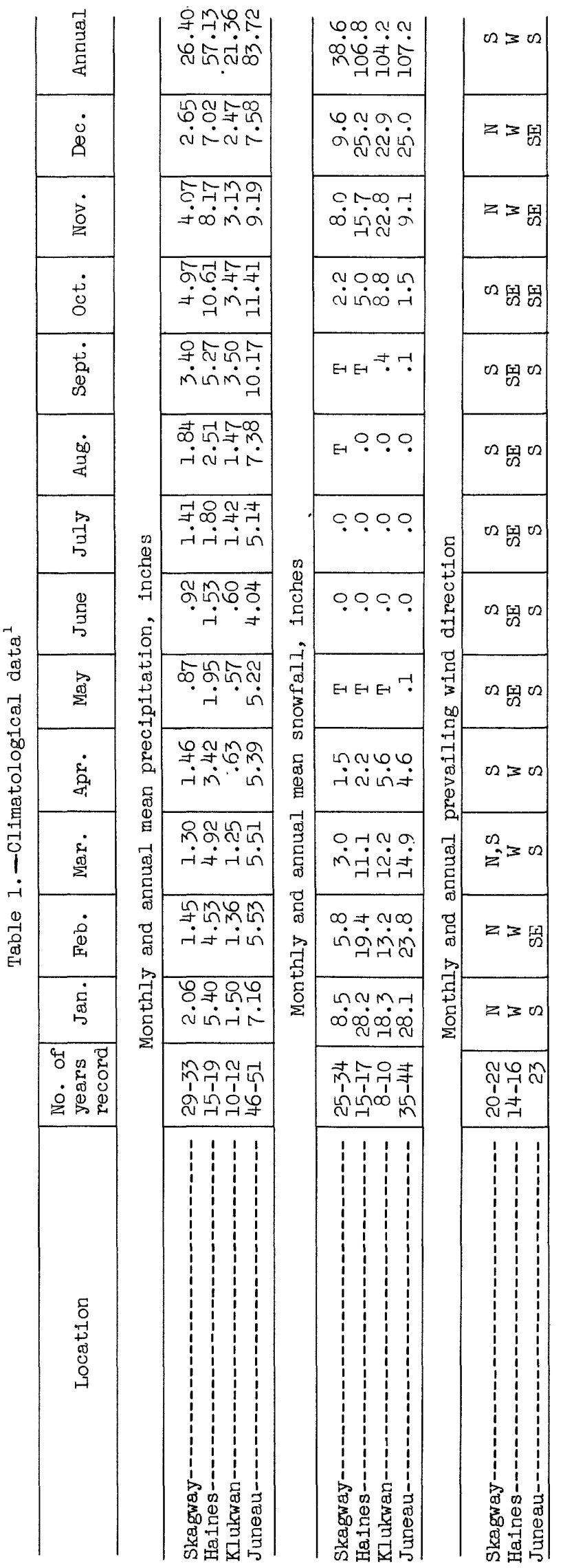

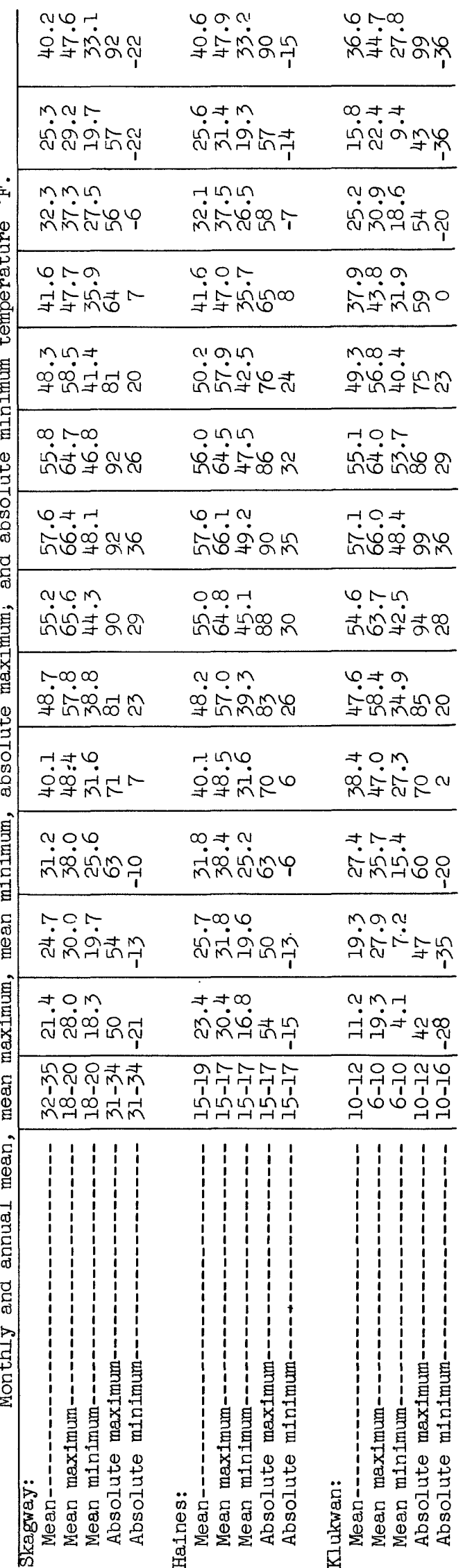


?⿻

幽宇

등

ํํํ요윰

ㄱ.

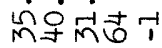

Mㄷ.

mंकó

7ㅇำ

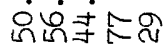

+6.

เท்่ல்

№

นำํำ

$\mathrm{N}+\mathrm{N}$

ثี่ல்

A.mo

守它宇品

mom

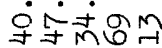

$\infty \sigma r$

мंळ

는

ํํํํํํㄷำ

$\infty \infty$.

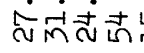

舟公公告

㠻少柴

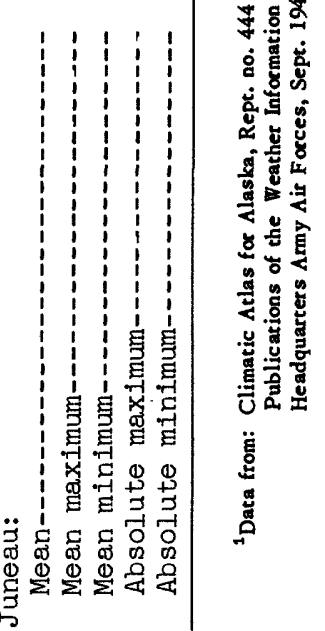


The most recent aerial photographs of the areas considered in this report were taken in 1948 by the U. S. Navy. These 9 by 9 inch single lens vertical photographs carry the symbol SEA. The photographs were taken with a 6-inch focal-length camera at a flying height of 20,000 feet and have an approximate scale of 1:40,000. The films are on file with the Topographic Division, Regional office of the U. S. Geological Survey, Denver, Colo.

Another set of aerial photographs was also taken by the U. S. Navy in 1948. These photographs were obtained at the same flying height, 20,000 feet, as the vertical photography described in the previous paragraph. They consist of two wing pictures, the axes of which are $18^{\circ}$ to the left and right of the vertical. The photographs were taken with a 12-inch focal-length camera and have an approximate scale of 1:20,000. These films are on file with the U. S. Forest Service, Department of Agriculture, Washington, D. C.

\section{DESCRIPTION OF SITES}

In the following descriptions, the various localities have been considered as individual units although some of these units may be combined as a larger unit or area. The Skagway-Taiya River units could be considered as one general area. Similarly, any large-scale development in the immediate vicinity of Haines undoubtedly would be accompanied in time, by other developments at several points on the Chilkat Peninsula, along Lutak Inlet, and from Haines toward Klukwan. In describing the locations individually several considerations are set forth, and from this information the possibility and effect of combining localities can be visualized.

\section{Skagway River valley}

Skagway is at the mouth of the Skagway River which enters the Taiya Inlet 3 miles from its upper end, and is about 90 airline miles north-northwest of Juneau. The Skagway River valley is shown on the Skagway B-l, Alaska quadrangle map and also in figure 3. Skagway is the tidewater terminus of the White Pass and Yukon Railroad. The inland terminus is Whitehorse, Yukon Territory, where connections can be made with the Yukon River boats and the Alaska Highway. The present population of Skagway is about 700. The population during the gold-rush days in the early part of the century has been estimated to have been as high as 35,000 , although this number may be excessive. Whatever the actual census was at that time, it was distinctly a gold-rush boom-town type of population, and these figures should not be taken as a measure of the size of a modern city that could be developed there.

The flat bottom of the Skagway River valley for $2 \frac{1}{2}$ miles upstream from its mouth is only half a mile wide at the widest point. It narrows and is less than a quarter of a mile wide at the mouth of the East Fork which enters at about mile 4 . The altitude at the mouth of the East Fork is slightly more than 200 feet; thus the average stream gradient is 50 feet per mile in the first 4 miles. Upstream from the mouth of East Fork the stream gradient is steep and irregular and large flat areas are lacking. The channel of the Skagway River is only a few feet below the canyon floor, and protective works are necessary to keep it from changing its course and causing extensive damage to the town and railroad bed. At present a gravel levee about 2 miles long affords this flood protection.

The valley walls of the Skagway River valley are composed of quartz diorite, a coarse-grained, massive, igneous rock that comprises most of the Coast Range batholith extending through the core of the Coast Range. The valley floor is composed of stream-laid sand and gravel that completely bury the bedrock surface of the valley. The depth to the bedrock surface is not known, but it is almost certainly several hundred feet. In the center of the valley in the town of Skagway, bedrock is possibly as much as 600 feet below the surface. This valley fill could provide an unlimited supply of sand and gravel for construction purposes.

The main climatic features are summarized in table 1. Precipitation and snowfall, 26.4 inches and 38.6 inches respectively, are rather low for southeastern Alaska. Temperatures range from a minimum of $-22 \mathrm{~F}$ to a maximum of $92 \mathrm{~F}$, the annual mean being $40.2 \mathrm{~F}$. Information is not available on the wind velocities, but the winter winds in Lynn Canal may be extremely severe having velocities more than 100 miles per hour; the stronger winds are prevailing northerly. A comparison of precipitation, and temperature for Juneau, Haines, Skagway, and Klukwan is shown graphically in figure 2.

The present water supply for Skagway is obtained mainly from Lower Dewey Lake, but some residents have individual wells. The following paragraph on the Dewey Creek basin has been abstracted from "Waterpowers, southeast Alaska" (U. S. Federal Power Commission and U. S. Forest Service, 1947, p. 75-76).

"Dewey Creek enters the Taiya Inlet 2.3 miles southwest of Skagway. There are two lakes in the basin. Upper Dewey Lake has an area of 34.4 acres at the 3,073 foot elevation and Lower Dewey Lake has an area of 32.8 acres at the 452 foot elevation. Icy Lake has an area of 3.4 acres at the 765 foot elevation, emptying into Icy Creek which flows one mile southeasterly to its confluence with Dewey Creek 300 feet upstream from the head of Lower Dewey Lake. Snyder Creek originally flowed into Dewey Creek 600 feet downstream from the outlet of Lower Dewey Lake but has been diverted from its natural course and now empties into Lower Dewey Lake. Reid Falls Creek, a tributary of the Skagway River, has been diverted also into Icy Lake, which in turn brings this water in to Lower Dewey Lake. The natural drainage area at the outlet of Lower Dewey Lake is 4.2 square miles. The drainage of Snyder Creek is 1.2 square miles, and that of Reid Falls Creek is 2.8 square miles, both of which have been diverted into Lower Dewey Lake making the total drainage area at the outlet of this lake 8.2 square miles. Comparing the precipitation at Skagway with that at Juneau it has been estimated that the discharge would be 3.5 second-feet per square mile and the mean discharge for the area draining into Lower Dewey Lake would be 29 second-feet. The discharge during winter months would be considerably below this figure, and there are no storage opportunities available whereby this flow could be equalized. "

The foregoing estimate of a mean discharge of $29 \mathrm{cfs}$ would correspond to a mean annual runoff of 48 inches. The mean annual precipitation at Skagway 
is 26.4 inches. The precipitation over the Dewey Lake drainage area is unquestionably greater than at Skagway but it seems doubtful if it is as great as the foregoing figures indicate. Consequently, the above-mentioned discharge of $29 \mathrm{cfs}$ is considered to be too great. The Dewey Lake basin therefore, does not offer adequate water supply for an industrial development and the supporting community but could probably meet most, if not all, of the demands for domestic water supply. (Estimated to require $11.6 \mathrm{cfs}$, page 2.)

The Skagway River has a drainage area of 149 square miles, 43 square miles of which are in British Columbia. An appreciable percentage of this area is covered with glaciers which affect the streamflow. There is a series of cascades 5 miles upstream from the mouth. During the winters of 1924-26, 28 discharge measurements (Water Powers, Southeast Alaska, p. 75-76) were made at the cascades to determine the low-flow characteristics. The nominal flow was $9 \mathrm{cfs}$, and the minimum discharge was $7 \mathrm{cfs}$ on April 24, 1925. It is apparent that the winter flows would be insufficient for even a small city and industrial development. A suitable storage site to equalize the flow throughout the year is not believed practicable in view of the steep gradient of the river. During times of moderate and high flows, the presence of sediment load from glacial action and stream erosion would present a difficult, if not an impracticable treatment problem.

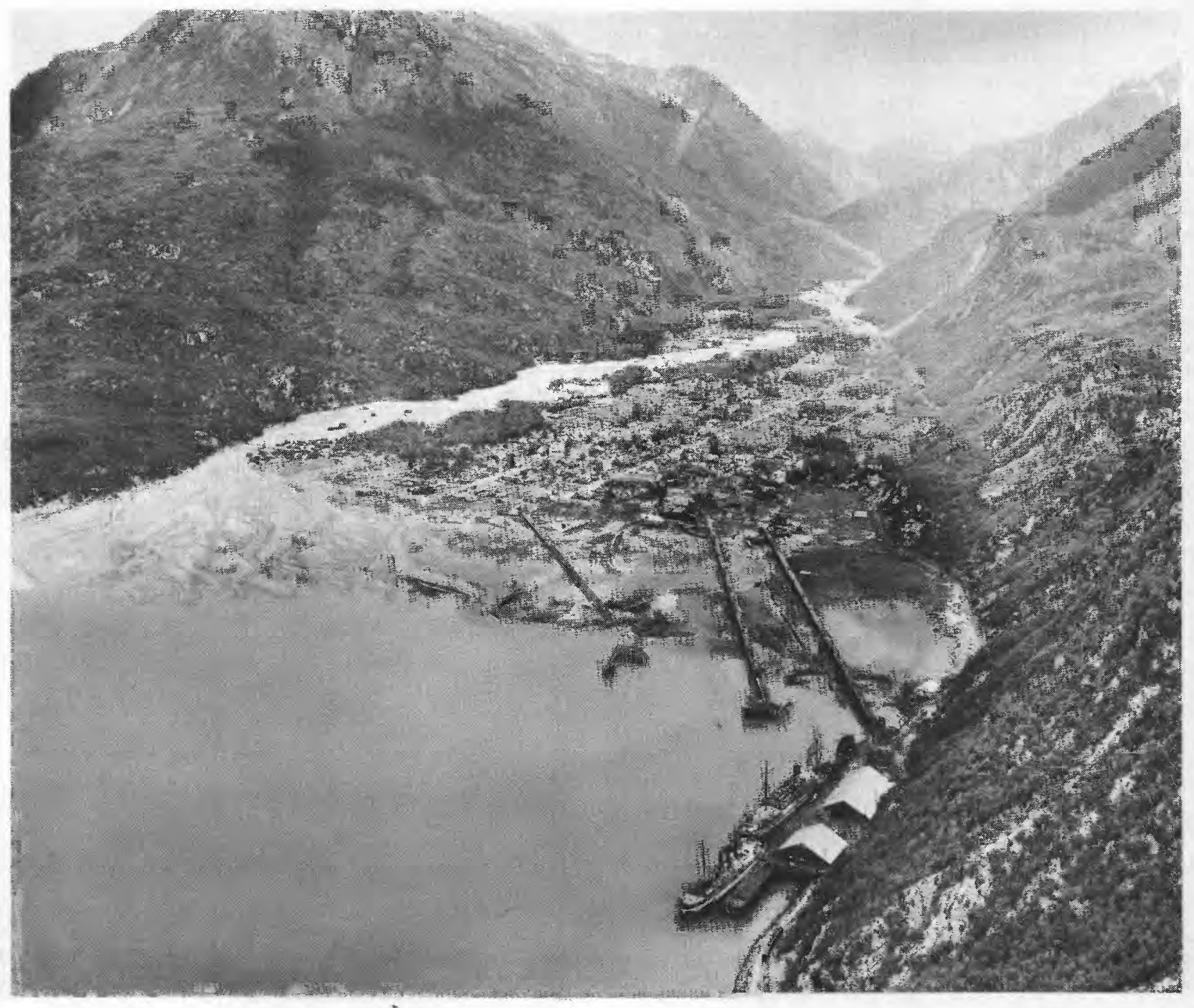

Figure 3. -Skagway and Skagway River valley. Photograph by U. S. Forest Service. 
One possible source of water supply would be from the tailrace or penstock of the proposed powerhouse on the Taiya River. This plan would require a conduit about 10 miles long.

Probably abundant ground-water supplies could be readily developed in the Skagway River valley. Cederstrom (1952, p. 15) reports that several residents have their own wells which range in depth from 16 to 30 feet, and that the water level in the center of town is only $4 \frac{1}{2}$ feet below the surface. The gravels are quite permeable and the ground water level throughout the valley is probably less than 10 feet below the surface.

One road from Skagway extends up the Skagway River valley about 3 miles. Another road, 7 or 8 miles long leads to a point about $2 \frac{1}{2}$ miles above the mouth of the Taiya River. This road is a narrow mountain road, but plans are being considered for its improvement. The White Pass and Yukon Railroad is a narrow-gage railway. Plans have been considered at various times, for the construction of a railroad from Prince George, British Columbia to Fairbanks, Alaska. If constructed, the railroads would connect at or near Whitehorse.

Proposals, chiefly by Skagway residents, have been made from time to time for roads to connect Skagway with Haines and Whitehorse. Connections to either of these towns would give access to the Alaska Highway. The mountainous terrain to be crossed by either of these routes creates tremendous difficulties for construction and maintenance.

Skagway is serviced winter and summer by oceangoing vessels of the Canadian Pacific Steamship Company. A modern well-equipped dock suitable for large vessels is maintained by the railroad. Although the Skagway River carries considerable sediment, filling of the harbor is not considered serious. The main difficulty encountered by ocean shipping is the strong north winds in Taiya Inlet during the winter. Harbor conditions are shown on U. S. Coast and Geodetic Survey chart 8303.

There is an airfield at Skagway but it can only accomodate small and medium-sized planes. Because the valley is so narrow larger planes cannot use this field.

The airline distance from Skagway to the powersite location is about 10 miles, and the transmissionline distance would be about the same.

The principal drawback to Skagway as an industrial site is the limited amount of available unoccupied land. Much of the valley is now occupied by the town of Skagway and the railroad and its appurtenances.

\section{Taiya River valley}

The Taiya River valley is shown on the Skagway B-1 and C-1, Alaska quadrangles. The Taiya River empties into the head of Taiya Inlet about 2 miles northwest of Skagway. For the lower 10 miles, the river flows in a flat bottomed canyon the maximum width of which is only three-fourths of a mile, and for much of this distance only one-half mile or less in width. The bottom ends abruptly against steep valley walls making avalanches and landslides an ever-present danger. The gradient of the lower section of the valley is flat; the 100-foot contour crosses at about mile 7 and the 400-foot contour at about mile 10. The channel is only slightly below general ground level, and the additional flow of water coming from the powerhouses might cause serious problems of flooding and erosion. The normal flow through the powerhouses will be about $5,000 \mathrm{cfs}$, but the flow will vary considerably and at times might be as high as $10,000 \mathrm{cfs}$. This value added to natural streamflow at times of high water may exceed the natural carrying capacity of the channel and cause flooding of the valley bottom. During the winter months the variation in flow coupled with ice accumulations and possible ice jams could also cause some difficulties. Establishment of industrial sites in the Taiya valley would likely necessitate considerable channel improvement and control.

The drainage area of the Taiya River basin upstream from the tributary entering from the west 3 miles above the mouth is 140 square miles. A large portion of this area is covered with glaciers that affect the streamflow.

The Taiya River valley is geologically similar to the Skagway River valley. The steep valley walls are composed of quartz diorite and the flat valley floor is composed of stream-laid silts, sands, and gravels. Because of the lower gradient of the Taiya River as compared with the Skagway River, the valley floor, particularly near the mouth, is made up of a large amount of silt. As a consequence the valley floor is poorly drained. In other respects the Taiya River valley has the same geologic features as the Skagway River valley.

Except for one or two homesteaders there are no settlers in the valley. During the gold-rush days the town of Dyea was at the mouth of the river. Dyea has long been abandoned and destroyed.

As far as is known no weather records along the Taiya River valley are available. Considering the similarilty of general features and proximity thereto, precipitation, snowfall, temperature, and wind direction along the lower part of the Taiya River valley no doubt would be similar to those observed at Skagway.

Water supply from the Taiya River valley is probably impracticable in view of its glacial characteristics. There are no known lakes from which a source of water could be obtained. Abundant ground-water supplies undoubtedly could be obtained from shallow wells dug in the valley fill. As mentioned for Skagway, a supply could be obtained from the powerhouse tailrace or penstock.

A narrow gravel roąd from Skagway leads to the lower part of the valley.

No rail or port facilities exist at present. A connection to the White Pass and Yukon Railroad at Skagway would require 8 to 10 miles of line. Dock facilities for steamers could be constructed along either side of the Taiya Inlet and less easily at the head of the Inlet. Extreme winter winds, as high as 100 miles per hour, may prohibit year-round docking at the head of Taiya Inlet. 
No air transportation facilities exist. Conditions for an airfield are somewhat more favorable than at Skagway, but here also the narrow valley would probably make it difficult to use large planes.

Industrial development in the Taiya River valley would be at the source of power and would have the distinct advantage of requiring only short transmission lines with their consequent low-maintenance costs and infrequent breakdown.

\section{Ferebee River valley}

The Ferebee River is shown on the Skagway, Alaska Reconnaissance Series quadrangle. It flows into Taiyasanka Harbor about 10 miles south-southwest from Skagway. The valley is long and narrow and has a strip of flat land in the valley bottom only half a mile wide. The stream gradient is about 30 feet per mile. The area of the drainage basin is 100 square miles. Suitable areas for a town and industrial sties are limited.

No climatic records are available for the Ferebee River valley. The nearest point that has record is Haines, 6 miles to the south. Values for precipitation and snowfall will likely fall between those for Haines and Skagway, probably being nearer the values for Haines than for Skagway. Temperatures would likely be quite comparable.

Geologically the valley is similar to the Skagway River valley.

Owing to its glacial character, the Ferebee River is not a suitable source of water supply. Ample supplies of ground water probably could be obtained from shallow wells dug in the valley floor. Outside sources would be the powerhouse tailrace or penstock on Taiya River which would require a conduit more than 20 miles long, or Chilkoot Lake which would require a conduit about 8 miles long.

There are no transportation facilities in the Ferebee River basin. Conditions are not favorable for either highway or railway development nor for landing fields for aircraft. Amphibian or floatplanes could use Taiyasanka Harbor when tide conditions were favorable. At extreme low tide nearly all the water flows out of this harbor. The conditions in this harbor are shown on U. S. Coast and Geodetic Survey chart 8303.

The length of transmission line to reach the area at the mouth of the Ferebee River would be about 20 miles, mostly along steep rugged mountain slopes.

The Ferebee River valley is not a desirable industrial and community site because of its isolation from transportation facilities and its limited area.

\section{Lutak Inlet}

The area adjacent to Lutak Inlet is shown on the Skagway, Alaska Reconnaissance Series quadrangle map.

Lutak Inlet is 4 miles long and 1 mile wide, lying in a northwest-southeast direction. The Chilkoot River empties into the head of the inlet. Chilkoot Lake, at an altitude of less than 100 feet, occupies the lower end of the Chilkoot River valley, the lake outlet is about 1 mile from the head of the inlet. An area of about 1 square mile between the lake outlet and the head of the inlet is fairly flat and ranges from 125 to 175 feet above sea level. It could be used for a small townsite and industrial site.

Both shores of Lutak Inlet are very steep; the northeast shore is steeper than the southwest. Any possible site locations along the shores of the inlet would be limited in extent.

The steep valley walls of Lutak Inlet are composed of massive fresh quartz diorite on the northeast side and massive greenstone and hornblendite on the southwest side. The valley floor consists of a thick fill of stream and glacial-laid deposits of sand and gravel intermixed with talus deposits from the steep valley walls. The low area that dams the Chilkoot River to form Chilkoot Lake is a recessional moraine of the glacier that formerly occupied the valley. It consists of the typical assemblage of unsorted rock material ranging from clay to large boulders.

The Chilkoot River drainage basin has an area of 117 square miles above the lake outlet, and the lake has an area of 2.5 square miles.

No climatic records are available. The nearest records are at Haines, 7 miles to the southeast. Precipitation is undoubtedly less than at Haines although snowfall and temperature are probably comparable.

The runoff from the Chilkoot River should provide more than an adequate water supply. If river flow during the winter should be too low to meet the demand, storage could be provided in Chilkoot Lake. As an example; raising the lake 25 feet would provide roughly 40,000 acrefeet of storage or more than one-half of the assumed annual demand. There are several small glaciers in the basin, but their area in proportion to the total is small. The lake is turbid with glacial silt, and the water would have to be treated to remove the rock flour in order to be suitable for domestic or industrial use.

Ground-water supplies could be obtained easily by wells dug in the valley fill upstream from Chilkoot Lakeit is doubtful if the recessional moraine at the mouth of Chilkoot Lake is sufficiently permeable to provide ground water.

The outlet of Chilkoot Lake is 9 miles, shoreline distance,from Haines. At present a road extends 5 miles from Haines along the southwest shore of Lutak Inlet. Four miles of new road would connect this area with Haines and, via the Haines Cutoff, with the Alaska Highway.

Extension of railroad facilities from Skagway to connect with this area would require about 35 miles of line, most of which is along precipitous mountain slopes.

Lutak Inlet provides the best harbor for anchorage of ocean-going vessels in the entire area of Lynn Canal north of Berners Bay. Details are shown on U. S. Coast and Geodetic Survey chart 8303. Its long axis is transverse to the major air-drainage pattern which is both 
up and down Lynn Canal. The inlet is sufficiently broad and long to permit adequate maneuverability of large vessels, and the bottom is deep enough so that good holding ground for anchoring can be reached easily. Dock facilities are now under construction on the southwest shore of Lutak Inlet at a point 5 miles from Haines. The initial facilities are being built primarily for tankers to supply the pipeline to the interior of Alaska. These facilities probably could be expanded as the demand warranted.

In view of the rather limited area available at the outlet of Chilkoot Lake, conditions for the development of an airfield to accommodate large landplanes are not favorable. Furthermore, the surrounding topography is unfavorable. Facilities for floatplanes could readily be made available in Lutak Inlet or in Chilkoot Lake.

The airline distance from the head of Lutak Inlet to the power site on the Taiya River is 18 miles, and the shoreline distance is 30 miles. The length of transmission line would be between these two values but probably would approach 25 miles, most of which would be along precipitous mountain slopes.

\section{Haines and vicinity}

Haines is 75 miles north-northwest from Juneau, at the upper or northwest end of the Chilkat Peninsula. This peninsula juts out from Mount Ripinski and extends southeastward 12 miles with Chilkoot Inlet on the northeast and Chilkat Inlet on the southwest. It ranges in width from half a mile at the narrowest point to 2 miles at the widest point. The maximum altitude attained is between 1,700 and 1,800 feet at a point 4 miles southeast from Haines. The area is shown on the Skagway, Alaska Reconnaissance Series quadrangle. An aerial view is shown in figure 4.

Haines lies in a saddle area between the foot of Mount Ripinski and the small mountain 4 miles to the southeast. At the narrowest point the saddle is threefourths of a mile wide between Chilkoot and Chilkat Inlets and less than 100 feet in altitude. From the low point of the saddle the ground rises in moderate slopes in either direction. There is a compact area of more than 2,000 acres that is below the 300 -foot contour surrounding this saddle. In addition there are areas of limited extent at other places along either shore of the peninsula that are considered favorable for industrial sites. The saddle area between the head of Flat Bay and Chilkat Inlet, 6 miles southeast from Haines, is fairly flat, probably about 200 acres below the 200-foot contour.

Topographic conditions in the Haines and vicinity area are considered the most favorable of any of the locations described in this report. Utilization of the maximum amount of available sunlight could be attained to a greater degree here than at any of the other localities with the possible exception of Juneau and vicinity. This area would permit the location of industrial sites and the accompanying city, and would allow adequate room for subsequent expansion in keeping with the most acceptable precepts of modern city planning.

The bedrock of the Chilkat Peninsula is dominantly massive greenstone that has been metamorphosed to a hard dense rock. Most of the low-land areas are veneered with glacial till and raised beach clays and gravels, ranging in thickness from a few feet to 25 or 30 feet on most of the peninsula except in the vicinity of Haines and Chilkoot Barracks. The bedrock lies at least several hundred feet below the land surface. Several wells (Cederstrom, 1952, p. 14) have been dug in this material, one of which reached a maximum depth of 512 feet. None of them are now used, and local residents are not too sure of their depth.

Weather data for Haines are shown in table 1 and in figure 2. The mean annual precipitation is 57 inches. The mean annual snowfall is 107 inches and is concentrated in the 4 months from November through February. Extremes of temperature that have been recorded range from a minimum of $-15 \mathrm{~F}$ in January to a maximum of $90 \mathrm{~F}$ in July.

Haines at present derives its water supply from a small creek draining from Mount Ripinski about $1 \frac{1}{2}$ miles northwest of the town. This supply is barely adequate, and during winter the pipeline often freezes, depriving the entire town of water. At such times the town obtains water from nearby Chilkoot Barracks which is supplied by Lilly Lake, a small lake $2 \frac{1}{2}$ miles southeast of town. Gravity flow carries the water through $1 \frac{1}{4}$ miles of 5 -inch pipe and $1 \frac{1}{4}$ miles of 3 -inch pipe to a storage tank at the barracks. It is estimated that if leaks in the line were repaired Lilly Lake could provide an average of $150 \mathrm{gpm}$ throughout the year. This quantity is sufficient water for the present community, but it does not allow for any expansion. At one time Chilkoot Barracks obtained its water from Haska Creek across Chilkat Inlet. A pipeline was laid across the mud flats, but because of damage by shifting sands the pipeline was abandoned. Improvements to the water supply and distribution system for Haines was in progress during the summer of 1952.

From the limited information available, it appears that adequate ground-water supplies are not available in sufficient quantities for the size of community contemplated in connection with the Yukon-Taiya Project. Surface-water supplies are not readily obtainable in the Haines area, and this situation is one of the major drawbacks of the area as a site for industrial development. Two sources of surface water are available: Chilkoot Lake and Chilkat Lake. Chilkoot Lake has already been discussed under Lutak Inlet. Delivering water from Chilkoot Lake to Haines would require a conduit between 9 and 10 miles long. The altitude of Chilkoot Lake is less than 100 feet and most of this fall would be absorbed in the conduit; thus pumping to an appropriate storage reservoir would be necessary to obtain a gravity distribution with sufficient pressure.

Chilkat Lake is 19 miles northwest of Haines and 3 miles southwest of Klukwan. It drains into the Tsirku River which in turn joins the Chilkat River near Klukwan. The lake is between 5 and 6 miles long, ranging in width from a few hundred feet to $1 \frac{1}{2}$ miles. The lake has an area of 3.9 square miles or 2,500 acres. The altitude of the lake surface is about 200 feet and is only about 15 to 20 feet above the level of Tsirku River. The drainage tributary to the lake is 38 square miles. No records are available on the outflow from the lake. Klukwan has a mean annual precipitation of 21 inches. The mean annual precipitation over the Chilkat Lake drainage area would 
undoubtedly be greater because of the higher altitudes of the basin. Using the value of 21 inches and assuming that essentially all the precipitation appears as runoff, the annual discharge from the lake would exceed 40,000 acre-feet, which is only slightly more than half the assumed annual demand. Actual discharge unquestionably would be much greater than the above figure but at the same time might not reach the estimated 72,000 acre-feet annual demand (see p. 2). The difference would have to be obtained from some supplemental source. Storage in the lake could be provided readily to equalize the flow throughout the year. For instance; raising the lake level 20 feet would provide more than 50,000 acre-feet of storage capacity. Conveying the water from Chilkat Lake to the Haines area would present many problems. The Chilkat River would have to be crossed with an appropriate conduit, and, in view of the channel conditions, would be difficult. A diversion at or near the outlet of the lake would require a conduit about 20 miles long to bring the water to the Haines area. This length could be shortened by several miles if it were practicable to divert water from a point near the head of the lake, by means of a tunnel about 2 miles long through the ridge between the lake and the Chilkat River. Pumping would be required to deliver the water to a suitable reservoir or storage tank for gravity distribution. Chilkat Lake has no glacial drainage, and the water is clear. Removal of turbidity would not be necessary as is the case with water from Chilkoot Lake.

A highway 154 miles long and originating at Haines, known as the Haines Cutoff, connects with the Alaska Highway at mile 960, 100 miles west of Whitehorse and 565 miles southeast of Fairbanks. A road from Haines extends down the southwest shore of the Chilkat Peninsula. between 5 and 6 miles, and crosses the narrow neck of the peninsula to the head of Flat Bay. A road also extends northwestward along the shore of Lutak Inlet for 5 miles.

An automobile ferry service operates between Haines and Tee Harbor, which is 18 miles northwest of Juneau. This ferry operates only when the Haines Cutoff is open.

Connection with the present railroad facilities at Skagway would require about 45 miles of line, most of which would be along steep mountain slopes.

At present there is a small pier at Haines at which large steamers can dock. As far as depth of .water is concerned, suitable dock locations are readily available along the Chilkoot Inlet side of the

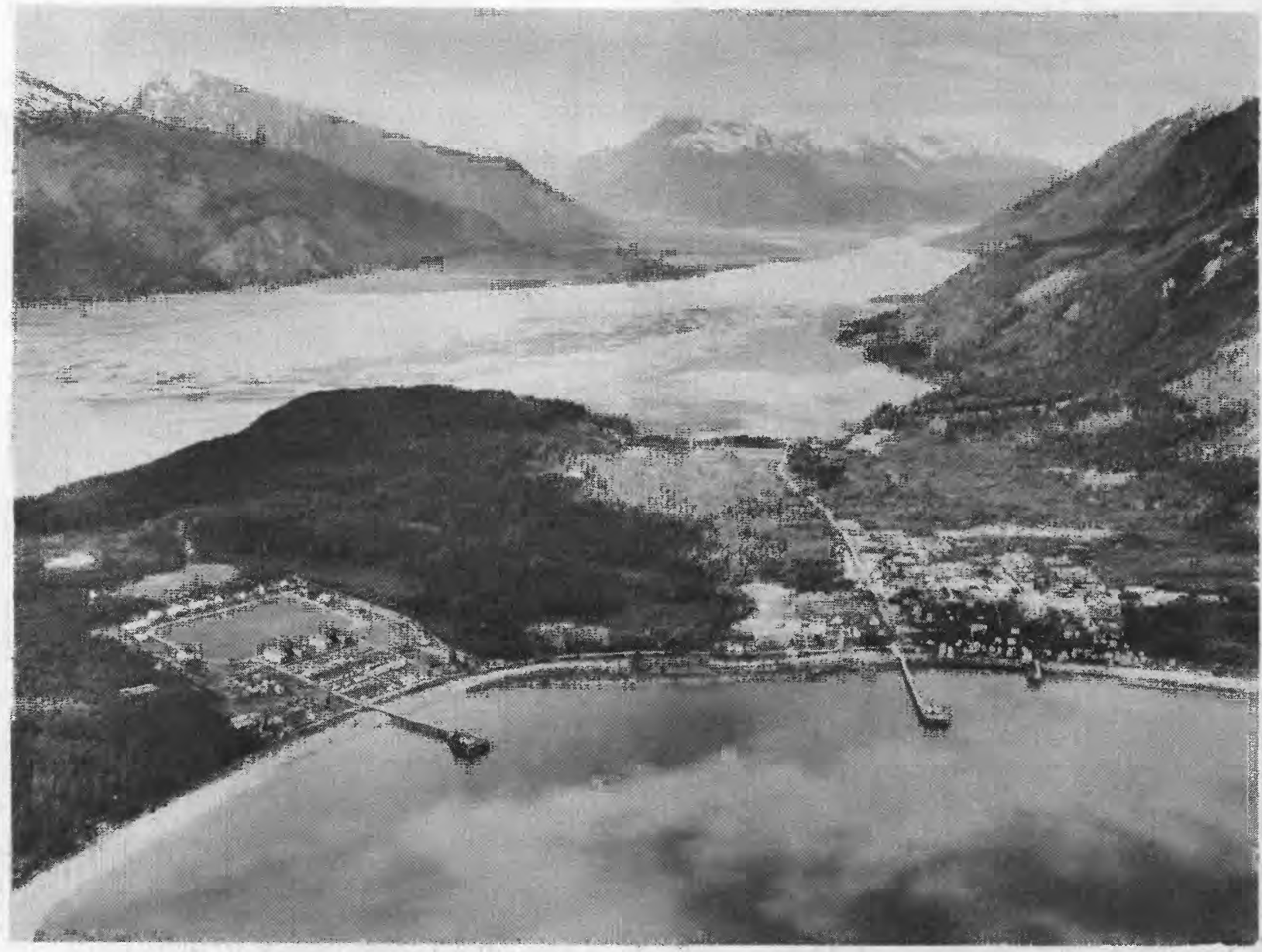

Figure 4. - Haines (right) and Chilkoot Barracks (left). Chilkat River in right background. Portage Cove in foreground. Photograph by U. S. Forest Service. 
peninsula. Winds in the winter cause some difficulty in docking. The Chilkat Inlet side is not a favorable location as the inlet is filling rapidly with silt from the Chilkat River. These two inlets are shown on U. S. Coast and Geodetic Survey chart 8303.

There is a small airstrip 2 miles northwest of Haines which is now used by the planes serving this area. These planes are comparatively small although a DC-3 plane probably could use the strip. The existing airstrip could be enlarged or other locations found where a field suitable for larger planes could be developed. Daily air service is now available to Juneau and Skagway.

Haines is 23 airline miles from the power site on the Taiya River. A transmission-line distance somewhat greater, probably nearly 30 miles, would be required to reach the Haines area. As previously mentioned, most of the transmission line would be along steep mountain slopes.

\section{Klukwan and vicinity}

Klukwan, an Indian village, is 23 miles by road northwest of Haines along the Haines Cutoff. The area is shown on the Skagway, Alaska Reconnaissance Series quadrangle map. Klukwan is on the northeast bank of the Chilkat River opposite the mouth of the Tsirku River and 2 miles downstream, southeast, from the confluence of the Klehini and Chilkat Rivers. Limited areas for town and industrial sites are available along the left bank of the Chilkat River between Klukwan and the junction of the Klehini and Chilkat Rivers. On the opposite side of the river are two areas worthy of consideration. One of these is enclosed by the Tsirku River, Little Salmon River, Klehini River, and Chilkat River. The other is the area between Chilkat Lake, Tsirku River, and Chilkat River.

Klukwan is on the outer edge of an alluvial fan formed by the rock debris from a small stream that drains from the mountain range above Klukwan. The fan gradually slopes upwards from an altitude of 120 feet at the shore of the Chilkat River to about 800 feet at the base of the mountain where the stream spreads out over the fan. The material in the fan consists largely of sand and silt at the outer margins, and toward the mountain front the material is increasingly coarse so that at the front the rock and debris contains many large boulders. The fan has formed since a glacier occupied the Chilkat valley, and, is still being added to every time the stream floods. It is reported that the village of Klukwan was destroyed many years ago when the stream flooded and debris from the mountain slopes spread over the village. If any large and valuable installations were constructed on the Klukwan fan, means would have to be provided to constrict the stream to a fixed channel to prevent damage in time of flood.

The lowland areas across the Chilkat River from Klukwan offer some possibilities as favorable sites for industrial development. The area enclosed by the Tsirku, Little Salmon, Klehini, and Chilkat Rivers is composed largely of river-deposited gravels only slightly above river level, whereas the area enclosed by Chilkat Lake, Tsirku River, and Chilkat River is largely composed of bedrock and rises as high as 750 feet above river level.
Weather conditions at Klukwan are shown in table 1 and in figure 2. The mean annual precipitation is 21 inches, thus showing the effect of its inland location. As noted above, the precipitation at Haines, 23 miles to the southeast, is 57 inches. Although the mean annual precipitation at Klukwan is only slightly more than one-third that at Haines, it is interesting to note that the values for annual snowfall are essentially the same, 104 and 107 inches respectively. As shown in table 1 , the mean values of temperature for Klukwan are definitely below those for Haines and Skagway. Extreme temperatures, however, vary from $-36 \mathrm{~F}$ to $99 \mathrm{~F}$, both extremes are beyond those for Haines and Skagway.

The water supply for any development in the Klukwan area would either be from ground-water sources, which are entirely undeveloped, or from Chilkat Lake, which was ciescribed in the previous section.

As previously stated, Klukwan is located on the Haines Cutoff, 23 miles from Haines. Roads could be extended to the two areas mentioned which are on the opposite side of the Chilkat River. The wide and shifting nature of the river channel would cause some problems in bridge location, construction, and maintenance.

Extension of rail facilities to connect with the railroad at Skagway seems out of the question. If the resulting industrial development requires movement of large volumes and tonnages, a railroad from the power sites to connect with dock facilities at tidewater would be necessary.

There are no airfields in this area at present. It is believed that topographic conditions are such that an airfield suitable for large planes could be readily located and developed.

The straight-line distance from Klukwan to the power site on the Taiya River is 22 miles. This route crosses two valleys at points less than 1,000 feet in altitude and three ridges more than 5,000 feet in altitude. A transmission line following fairly close to the shore from the power site to Haines and then following the road would be about 70 miles in length. The length of the transmission line would be between these extremes, probably about 50 miles.

\section{Haines to Klukwan}

Certain areas of limited extent are available along the road from Haines to Klukwan. These are the gentler slopes and on some of the flat areas along the river channel. Attention should be called to the alluvial fan at the abandoned Indian town of Kalwatta at mile 18 on the Haines Cutoff. This fan is similar to the one at Klukwan.

Climatic conditions along this area would vary between the conditions shown for Haines and Klukwan, actual conditions depending on the location considered. As previously noted the precipitation at Klukwan is only slightly more than one-third that at Haines. Whether or not the precipitation decreases uniformly or irregularly on ascending the valley is not known. 
Water supply would be from ground-water sources or from Chilkat Lake. ing road.

Any sites along this area would be near the exist-

Extension of rail facilities from Skagway to this area is not considered feasible because of the rugged terrain. However, if industrial development requires the movement of a large volume and tonnage, a railroad from the industrial sites to connect with dock facilities at tidewater could be constructed.

Whether or not suitable airfields could be developed would depend on the location.

\section{Berners Bay}

Berners Bay is on the east side of Lynn Canal, 35 miles north-northwest of Juneau and 55 miles southsouthwest of Skagway. Portions of Berners Bay are shown on the Juneau D-4 anc C-3 quadrangle maps, and in the aerial view in figure 5. The principal streams entering the Bay are Berners River, Lace River, Antler River, and Cowee Creek, all originating in glaciers. Canyon Creek and South Fork Cowee Creek, tributaries of the Cowee River, are nonglacial. There are comparatively flat areas at several points along the shore of the bay and at the mouths of the several streams entering it.

Weather records are not available for the Berners Bay area but it is believed that conditions are similar to those recorded at Juneau.

Possibilities for development of ground-water supplies have not been investigated.

The best possibilities for surface-water supply appear to be from Canyon Creek and South Fork of Cowee Creek, nonglacial tributaries of Cowee Creek. Canyon Creek has a drainage area of 5 square miles and South Fork of Cowee Creek has a drainage area of 6 square miles. Owing to the low altitude of the basins the runoff will follow closely the precipitation

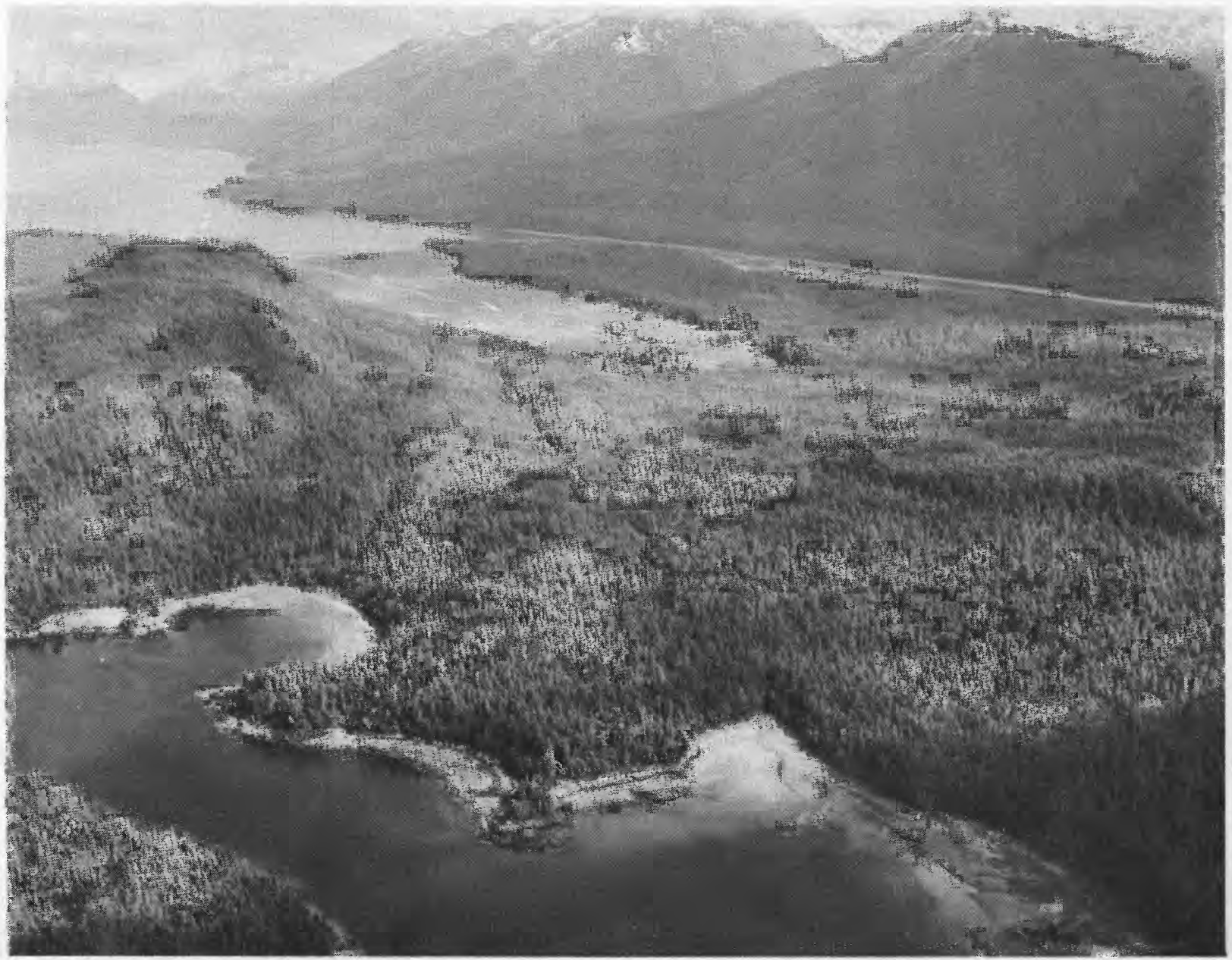

Figure 5. - Berners Bay, left background. Bridget Cove in foreground. Cowee Creek in center. Photograph by U. S. Forest Service. 
pattern. Minimum mean monthly precipitation at Juneau is 4 inches in June. Assuming an equal amount of runoff the combined areas would contribute 2, 300 acre-feet in June which is less than one-half the proportionate share of the estimated annual demand of 72,000 acre-feet. The other streams are all of glacial origin, consequently their suitability as a source of water is doubtful.

At present there are no roads in the area. A road from Juneau ends at Eagle River, 10 miles southeast of the south end of the Bay. A road could readily be constructed from the south end of Berners Bay to connect with the Juneau road at Eagle River.

There are no railroad facilities in the area and construction of any hardly seems justified.

Although there are no dock facilities, shore and water conditions would readily permit their construction. Berners Bay is shown on Coast and Geodetic Survey chart 8302.

At present there are no airport facilities. It is believed that topographic conditions at various points around the bay are favorable for location and construction of airfields.
A transmission line 60 to 65 miles in length would be required to reach from the power site on the Taiya River to Point St. Mary, the north end of the opening into Berners Bay. The additional distance required would depend on the location of the industrial sites around the bay. The transmission line would, for the most part, be along steep, rugged mountain slopes.

\section{Juneau and vicinity}

Juneau occupies a limited and almost fully utilized area that does not provide much opportunity for city or industrial expansion. There are, however, several areas west and northwest of Juneau which are essentially unoccupied and are connected to Juneau by an all-weather road. Among these are the northeast and north sides of Douglas Island, Lemon Creek, Mendenhall Valley, Auke Bay, Tee Harbor, Pearl Harbor, and Eagle and Herbert Rivers. All of these areas are shown on Juneau B-2, $\mathrm{B}-3$, and $\mathrm{C}-3$, Alaska quadrangle maps. Juneau and adjacent areas is well shown in the aerial view in figure 6.

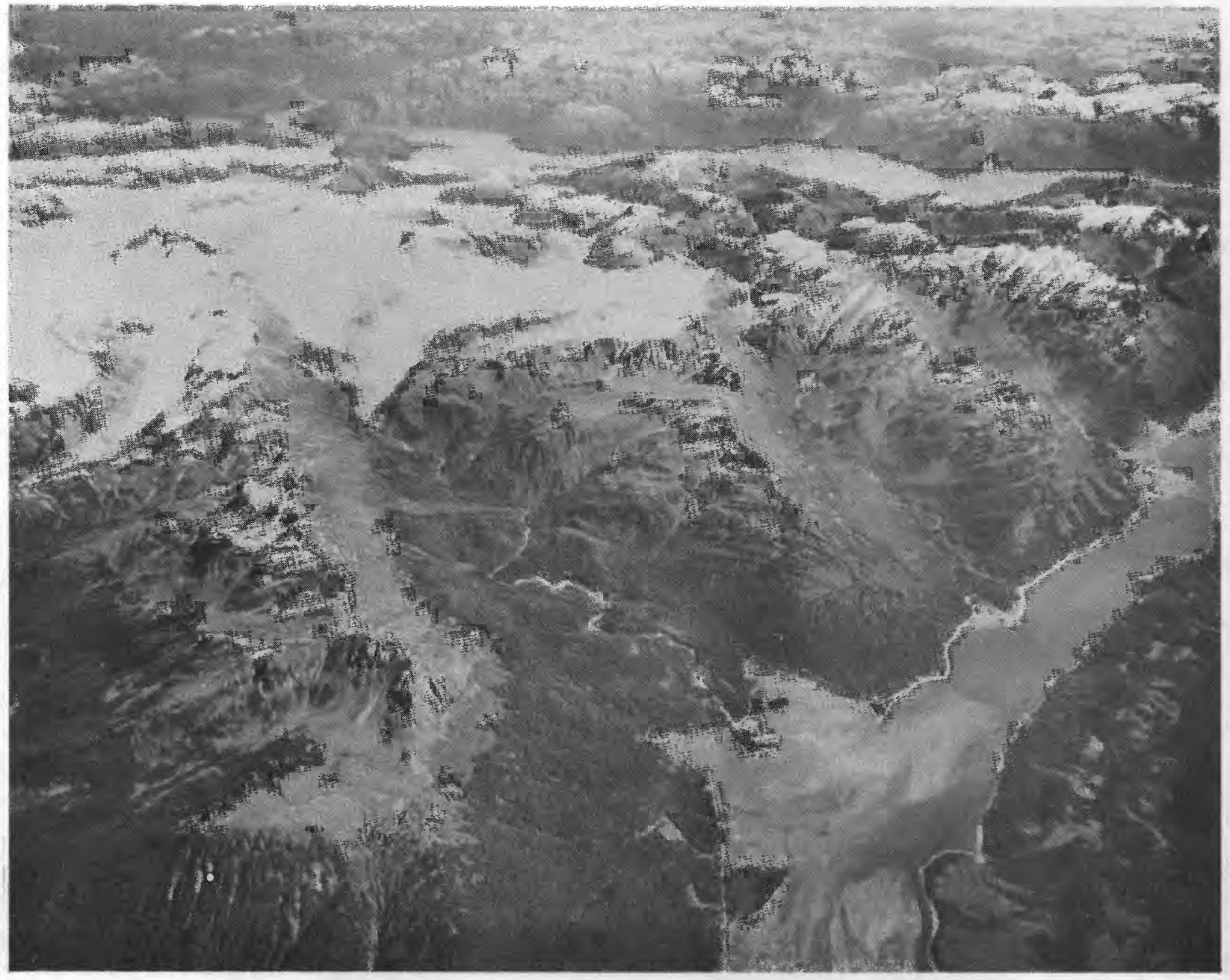

Figure 6. -Juneau and Gastineau Channel. Taku Inlet in distance. Photograph by U. S. Forest Service. 
The character of the subsurface of suitable sites ranges from bedrock veneered with glacial till and elevated beach deposits to silt, sand, and gravel valley-fill. Metamorphosed slate, graywacke, and lava flows can be expected a short distance below the surface on Douglas Island, Auke Bay, and Tee Harbor. Mendenhall Valley is a flat area of 3 to 4 square miles filled with a very thick deposit of glacial outwash consisting of silt, sand, and gravel. The nature of the materials is such that abundant ground-water supplies probably could be easily developed. Pearl Harbor, Lemon Creek, and Eagle and Herbert River valleys are low areas of limited extent largely composed of sand and gravel.

The climatic conditions for Juneau are shown in table 1 and figure 2 and are fairly representative for the areas north of town, except that precipitation values are probably about two-thirds those of Juneau. The snowfall at Juneau is about the same as at Haines and Klukwan.

Juneau and Douglas obtain their water from surface sources. Juneau has three systems, all privately owned, that divert water from streams issuing from the mountains back of town. Gold.Creek provides the principal source of water. Douglas obtains its water from a stream back of town. None of the systems is capable of much expansion and any development outside of the present city limits of Juneau and Douglas would have to obtain its water elsewhere. Possible sources of water are Fish Creek and other" streams draining northeasterly from Douglas Island, Montana Creek for the Auke Bay and Mendenhall Valley area, and Peterson Creek and Lake for Tee Harbor, Pearl Harbor, and Eagle and Herbert River valley areas. Ground-water supplies probably could be developed, particularly in the Mendenhall Valley and the Eagle and Herbert River valleys, but these areas should be investigated by test wells before definite statements can be made.

An all-weather road extends from Juneau to Douglas and 30 miles northwest to Eagle River. To extend the road from Juneau to either Skagway or Haines is virtually impossible because of the rugged terrain. A low-level road from Juneau up the Taku River valley to connect with feeder roads to the Alaska Highway has been proposed and discussed for many years. Such a road would require either a ferry or piling roadway across the tidal Taku Glacier.

There are no rail facilities at Juneau and development of any seems most unlikely.

Juneau has excellent dock and harbor facilities as well as a modern airport that accomodates four-engine planes. Daily air service is maintained to other Alaskan towns and to the States. Harbor and airport facilities could be expanded to handle increased traffic.

A transmission line from the Taiya River valley to Juneau and vicinity would be from 90 to 110 miles long and would cross very rugged terrain from Skagway to Berners Bay. Heavy snows, landslides, and icing conditions would make construction and maintenance a considerable problem. The interval from Berners Bay to Juneau is relatively low land and should not present any particular problem.

\section{RECOMMENDATIONS}

As a step in the further analysis of several general locations the following investigations are recommended:

1. Installation of recording anemometers at Skagway and Haines to obtain data on wind velocities and its relation to shipping problems. This data would also be useful in studying air pollution problems, which would undoubtedly be part of any industrial development, and would assist in determining the best relation between the location of industrial and residential areas. Data at these two stations would be reasonably applicable to other points in the Haines-Skagway area.

2. Installation of stream-gaging stations on the Skagway River, Taiya River, Chilkoot Lake outlet, and Chilkat Lake outlet. The streamflow data at the lake outlets would be primarily for water-supply studies. The streamflow data on the rivers would be useful not only for water-supply studies but also for flood control, channel improvement, and maintenance studies. Sediment and quality of water investigations should be incorporated with this stream-gaging program.

3. Exploration of ground-water potentialities in the locations most favorable for industrial sites.

4. Topographic mapping of areas under consideration on a scale of $1: 24,000$, with appropriate contour interval. Such maps would provide an adequate base for preliminary engineering designs and estimates as well as a base for geologic studies.

5. Geologic examination of dam sites at outlets of Chilkoot and Chilkat Lakes, and other areas under consideration for industrial and community developments.

\section{LITERATURE CITED}

Barrows, H. K., 1943, Water-power engineering, 3d ed., New York, McGraw-Hill Book Co., Inc. Cederstrom, D. J., 1952, Summary of ground-water development in Alaska, 1950: U. S. Geol. Survey Circ. 169. Engineering News Record, Aug. 28, 1952, v. 149, no. 9.

Tarr, R. S., and Martin, Lawrence, 1912, The earthquakes at Yakutat Bay, Alaska, in September 1899: U. S. Geol. Survey Prof. Paper 69.

United States Coast and Geodetic Survey, Sept. 1941. Tidal bench marks, southeast Alaska: T-28, p. 164.

United States Federal Power Commission and United States Forest Service, 1947, Water powers, southeast Alaska: U. S. Federal Power Comm. P-9, p. 75-76. 
